Jurnal Media Agribisnis Vol. 2 No. 2 Tahun 2017 Hal 85 - 91

Media Komunikasi Hasil Penelitian Bidang Ilmu Agribisnis

ISSN print 2548-7027

ISSN online 2541-6898

\title{
FAKTOR - FAKTOR YANG MEMPENGARUHI INVESTASI PEMERINTAH PADA SEKTOR PERTANIAN DI PROVINSI JAMBI
}

\author{
Mulyani \\ Program Studi Agribisnis, Fakultas Pertanian Universitas Batanghari \\ J1. Slamet Riyadi-Broni, Jambi. 36122. Telp. +6274160103 \\ email : m_yaniez@yahoo.co.id
}

\begin{abstract}
This research was conducted to analyse government investment in agriculture sector at Jambi Province. This research was held on June - September 2017 by collecting data from several agencies. It used a time series data for 10 years (2006-2015). This research applied multiple linear regression to analyse the data. The results show that 95.9\% of government investment in agriculture sector could be explained by domestic income variable, export-import growth of agriculture sector, real interest rate, rupiah exchange rate, previous government investment, and growth of agriculture sector. In fact the factors that had a significant effect were domestic income variable, , exportimport growth of agricultural sector, previous government investment and the growth of agriculture sector.
\end{abstract}

Keywords: government investment, agricultural sector, growth

\begin{abstract}
Abstrak
Penelitian ini dilakukan untuk menganalisis investasi pemerintah pada sektor pertanian di Provinsi Jambi. Penelitian dilaksanakan di Provinsi Jambi dengan mengumpulkan data dari beberapa instansi terkait, yang dilaksanakan pada bulan Juni 2017 sampai September 2017. Dimana penelitian ini menggunakan data time series, dengan rentang waktu 10 tahun (2006-2015). Analisis data pada penelitian ini menggunakan regresi linear berganda. Hasil penelitian menunjukkan $95,9 \%$ penyerapan investasi pemerintah pada sektor pertanian dapat dijelaskan oleh variabel pendapatan asli daerah,pertumbuhan ekspor-impor sektor pertanian, tingkat suku bunga riil, nilai tukar rupiah, investasi pemerintah pada tahun sebelumnya, dan pertumbuhan sektor pertanian. Dari faktor-faktor tersebut yang berpengaruh signifikan adalah Pendapatan asli daerah, pertumbuhan ekspor impor sektor pertanian, investasi pemrintah pada tahun sebelumnya dan pertumbuhan sektor pertanian.
\end{abstract}

Kata Kunci : investasi pemerintah, sektor Pertanian, pertumbuhan

\section{PENDAHULUAN}

Syafa'at, dkk (2005) berpendapat bahwa proses transformasi struktur ekonomi ke arah industrialisasi dan bertumbuhnya sektor-sektor modern (industri dan jasa) di masa lalu terlalu dipercepat (accerelated) dengan berbagai proteksi pemerintah dan mengarah kepada proses yang tidak matang (immature), dimana sektor pertanian dan pedesaan kurang mendapat perhatian dalam investasi di berbagai bidang di luar usahatani. Karena perkembangan sektor industri ternyata kurang atau tidak terkait secara langsung dengan sektor pertanian dan pedesaan, sektor pertanian dan pedesaan tidak dapat menyerap tenaga kerja lebih banyak. Hal ini mengakibatkan banyaknya tenaga kerja yang bermigrasi secara eksesif dari pedesaan ke perkotaan karena terjadinya excess supply. 
Jurnal Media Agribisnis Vol. 2 No. 2 Tahun 2017 Hal 85 - 91

Media Komunikasi Hasil Penelitian Bidang Ilmu Agribisnis

ISSN print 2548-7027

ISSN online 2541-6898

Sektor pertanian masih merupakan sektor yang mempunyai banyak peran dalam pertumbuhan ekonomi suatu wilayah, baik itu secara nasional maupun secara regional atau daerah. Pembangunan pertanian juga dapat membantu menjaga stabilitas perekonomian suatu wilayah regional maupun nasional karena harga produksi pertanian memiliki bobot yang besar dalam indeks harga konsumen sehingga dinamikanya amat berpengaruh terhadap laju inflasi. apabila dikaitkan dengan keterkaitan antara sektor pertanian dengan sektor industri, pembangunan sektor pertanian mampu meningkatkan kinerja sektor industri, karena terdapat keterkaitan yang erat antara sektor pertanian dengan sektor industri yang meliputi keterkaitan produk, konsumsi dan investasi.

Dari uraian diatas kita dapat melihat bahwa peran sektor pertanian dalam pertumbuhan ekonomi suatu wilayah baik dalam ruang lingkup region atau daerah maupun secara nasional sangat berpengaruh terhadap pertumbuhan ekonomi secara keseluruhan dalam suatu wilayah. Oleh karena itu, investasi pada sektor pertanian masih merupakan hal yang prospektif dalam meningkatkan pembangunan.sehingga dirasa perlu dilakukan tinjauan atau penelitian yang lebih mendalam tentang bagaimana investasi pada sektor pertanian. Dalam hal ini pada penelitian ini difokuskan pada faktor-faaktor yang mempengaruhi investasi pemerintah pada sektor pertanian di Provinsi Jambi.

Pembangunan ekonomi adalah suatu proses berkelanjutan yang mengikutsertakan pembangunan dari berbagai sektor yang menyusun suatu perekonomian. Dalam hal ini, sektor pertanian di Provinsi Jambi adalah salah satu sektor yang sangat mempengaruhi pertumbuhan pembangunan ekonomi wilayah di Provinsi Jambi. Hal ini dapat dilihat dari besarnnya nilai share sektor pertanian terhadap pembentukan PDRB total Provinsi Jambi. Dimana, nilai PDRB suatu wilayah dapat dijadikan sebagai indikator dalam menilai pertumbuhan ekonomi suatu wilayah.Akan tetapi, beberapa tahun terakhir laju pertumbuhan sektor pertanian di Provinsi Jambi cenderung mengalami fluktuasi yang menurun dari tahun ketahun.

Dalam proses pertumbuhannya, sektor pertanian tidak terlepas dari pengaruh berbagai variabel makro ekonomi (capital, labor, and technology). Dimana, antara satu variabel dengan variabel yang lain juga saling mempengaruhi. Pada pembentukan kapital (capital accumulation), selain dipengaruhi oleh tingkat output total juga dipengaruhi oleh total investasi pada sektor pertanian, dan pertumbuhan nilai ekspor dan impor sektor pertanian. Sedangkan investasi total merupakan penjumlahan nilai investasi pemerintah dan investasi swasta.

Pada variabel tingkat investasi, fluktuasinya tidak terlepas dari variabel lain. Investasi pada sektor pertanian ada yang berasal dari pihak swasta maupun pemerintah. Investasi pemerintah dapat dipengaruhi oleh pendapatan asli daerah sebagai sumber dana pemerintah dalam berinfestasi, pertumbuhan ekspor impor, tingkat suku bunga riil, nilai tukar rupiah, besarnya investasi pemerintah pada tahun sebelumnya dan pertumbuhan sektor pertanian..

Berdasarkan uraian di atas, maka timbul pertanyaan penelitian, mengenai penyerapan investasi pemerintah pada sektor pertanian di Provinsi Jambi dan faktor faktor yang berpengaruh nyata terhadap investasi pemerintah pada sektor pertanian di Provinsi Jambi. 
Jurnal Media Agribisnis Vol. 2 No. 2 Tahun 2017 Hal 85 - 91

Media Komunikasi Hasil Penelitian Bidang Ilmu Agribisnis

ISSN print 2548-7027

ISSN online 2541-6898

\section{METODOLOGI PENELITIAN}

Penelitian ini adalah mengkaji penyerapan investasi pemerintah pada sektor pertanian di Provinsi Jambi. Metode penelitian yang digunakan adalah metode penelitian histories. Data yang digunakan adalah berupa data sekunder yaitu data berkala (time series) selama 10 tahun dari tahun 2006 sampai tahun 2015. penelitian dilakukan melalui riset kepustakaan (Library Research) dengan melakukan pengumpulan data yang mempunyai relevansi terhadap penelitian dengan jalan mencari sumber literatur, laporan dari instansi pemerintah terkait, dan sumber data lainnya yang dianggap menunjang penelitian ini.

\section{Teknik Analisis Data}

\section{Uji Asumsi Dasar}

Uji Normalitas

Uji normalitas digunakan untuk mengetahui apakah populasi data terdistribusi normal atau tidak. Dalam penelitian ini uji normalitas akan dilakukan dengan menggunakan One Sample Kolmogrov- Smirnov test dengan menggunakan taraf signifikan 0,05. Data berdistribusi normal jika taraf signifikan $5 \%$ atau 0,05.

2. Uji Penyimpangan Asumsi Klasik

Uji Multi Kolinearitas

Uji Multi Kolinearitas bertujuan untuk menguji apakah dalam persamaan regresi ditemukan adanya korelasi antar variabel independen. Uji asumsi klasik multikolineariti hanya dapat dilakukan jika ada lebih dari satu variabel independen dalam persamaan regresi. Dalam penelitian ini uji multi kolineariti dilakukan dengan melihat nilai Variance Inflation Factor (VIF) dan Tolerance dalam model regresi.

3. Analisis Regresi Linier berganda

Analisis regresi linier berganda adalah hubungan secara linier antara dua atau lebih variabel independen $(\mathrm{X} 1, \mathrm{X} 2, \ldots, \mathrm{Xn})$ dengan variabel dependen $(\mathrm{Y})$. Analisis ini untuk mengetahui arah hubungan antara variabel independen dengan variabel dependen apakah masing-masing variabel independen berhubungan positif atau negatif dan untuk memprediksi nilai dari variabel dependen apabila nilai variabel independen mengalami kenaikan atau penurunan.

Persamaan regresi linier berganda sebagai berikut:

$$
\begin{aligned}
& \mathrm{Y}^{\mathrm{c}}=\mathrm{a}+\mathrm{b} 1 \mathrm{X} 1+\mathrm{b} 2 \mathrm{X} 2+\ldots .+\mathrm{bnXn} \\
& \text { Keterangan }: \\
& \mathrm{Y}=\text { Variabel dependen (nilai yang diprediksikan) } \\
& \mathrm{a}=\text { Konstanta (nilai } \mathrm{Y}^{\prime} \text { apabila } \mathrm{X} 1, \mathrm{X} 2, \ldots . \mathrm{Xn}=0 \text { ) } \\
& \mathrm{b}=\text { Koefisien regresi (nilai peningkatan ataupun penurunan) } \\
& \mathrm{X}=\text { Variabel independen }
\end{aligned}
$$

a. Analisis Korelasi Ganda ( R )

Analisis korelasi ganda (R) digunakan untuk mengetahui hubungan antara dua atau lebih variabel independen terhadap variabel dependen secara serentak. Dimana pedoman untuk memberikan interpretasi koefisien korelasi (Gaspersz v. 1991) sebagai berikut:

$$
\begin{aligned}
& 0,00-0,199=\text { sangat rendah } \\
& 0,20-0,399=\text { rendah } \\
& 0,40-0,599=\text { sedang } \\
& 0,60-0,799=\text { kuat } \\
& 0,80-1,000=\text { sangat kuat }
\end{aligned}
$$


Jurnal Media Agribisnis Vol. 2 No. 2 Tahun 2017 Hal 85 - 91

Media Komunikasi Hasil Penelitian Bidang Ilmu Agribisnis

ISSN print 2548-7027

ISSN online 2541-6898

b. Analisis determinasi

Sedangkan analisis determinasi digunakan untuk mengetahui persentase sumbangan pengaruh variabel independen secara serentak terhadap variabel dependen.

4. Pengujian Hipotesis

a. Uji Koefisien Regresi secara bersama-sama ( Uji F)

Uji F digunakan untuk mengetahui apakah variabel independen secara bersamasama berpengaruh secara signifikan terhadap variabel dependen (Y). Dengan kata lain, uji $\mathrm{F}$ ini dapat digunakan untuk mengetahui apakah sebuah model regresi dapat digunakan untuk memprediksi sebuah variabel dependen atau tidak.

F hitung dapat dicari dengan rumus sebagai berikut:

$$
\text { F hitung }=\frac{R^{2} / k}{\left(1-R^{2}\right) /(n-k-1)}
$$

Keterangan:

$\mathrm{R}^{2}=$ koefisien determinasi

$\mathrm{n} \quad=$ jumlah data atau kasus

$\mathrm{k} \quad=$ jumlah variabel independen

Jika $\mathrm{F}$ hitung > F tabel, H0 ditolak, maka dapat disimpulkan bahwa ada pengaruh secara signifikan antara variabel independen (lebih dari dua) secara bersamasama terhadap variabel dependen.

b. Uji Koefisien Regresi secara parsial (Uji t)

Uji $t$ digunakan untuk mengetahui apakah dalam model regresi variabel independen secara parsial berpengaruh signifikan terhadap variabel dependen.

T hitung dapat dicari dengan menggunakan rumus sebagai berikut:

thitung $=\frac{r \sqrt{n-k-1}}{\sqrt{1-r^{2}}}$

Keterangan :

$\mathrm{r}=$ koefisien korelasi parsial

$\mathrm{k}=$ Jumlah variabel independen

$\mathrm{n}=$ jumlah data atau kasus

dengan kaidah keputusan :

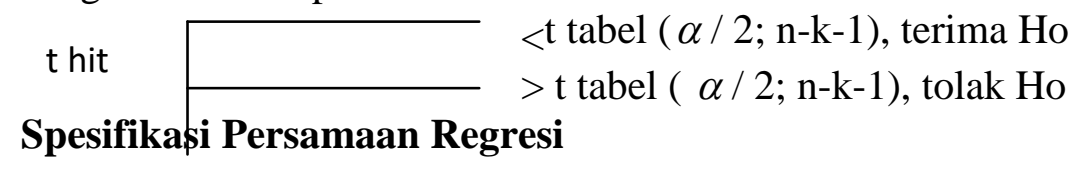

Investasi pemerintah : $\mathrm{KPT}_{\text {gov }}=\mathrm{d}_{0}+\mathrm{d}_{1} \mathrm{PAD}+\mathrm{d}_{2} \mathrm{PEM}+\mathrm{d}_{3} \mathrm{RIRT}+$

$$
\mathrm{d}_{4} \mathrm{ERT}+\mathrm{d}_{5} \mathrm{KPT}_{\text {gov } t-1}+\mathrm{d}_{6} \mathrm{PSP}+\mathrm{u}
$$

Dimana :

$$
\begin{array}{ll}
\text { KPT }_{\text {gov }} & =\text { investasi pemerintah (juta rupiah) } \\
\text { PAD } & =\begin{array}{l}
\text { pendapatan asli daerah pada tahun sebelumnya (juta } \\
\text { rupiah) }
\end{array} \\
\text { PEM } & =\text { pertumbuhan ekspor }- \text { impor sektor pertanian }(\%) \\
\text { RIRT } & =\text { tingkat suku bunga riil }(\%) \\
\text { ERT } & =\text { nilai tukar rupiah }
\end{array}
$$


Jurnal Media Agribisnis Vol. 2 No. 2 Tahun 2017 Hal 85 - 91

Media Komunikasi Hasil Penelitian Bidang Ilmu Agribisnis

ISSN print 2548-7027

ISSN online 2541-6898

$$
\begin{array}{ll}
\text { KPT }_{g o v} t-1 & =\text { investasi pemerintah pada tahun sebelumnya } \\
\text { PSP } & =\text { pertumbuhan sector Pertanian }(\%) \\
\mathrm{d}_{0}, \mathrm{~d}_{1}, \mathrm{~d}_{2}, \mathrm{~d}_{3}, \mathrm{~d}_{4}, & \mathrm{~d}_{5}, \mathrm{~d}_{6}=\text { Parameter penduga } \\
\mathrm{u} & =\text { Standar error }
\end{array}
$$

Hipotesis : $\mathrm{d}_{1}, \mathrm{~d}_{2}, \mathrm{~d}_{4}, \mathrm{~d}_{6}>0$ dan $\mathrm{d}_{3}, \mathrm{~d}_{5}<0$

Hipotesis:

1. Pendapatan asli daerah, pertumbuhan ekspor impor sektor pertanian, Nilai tukar rupiah dan pertumbuhan sektor pertanian berpengaruh positif terhadap investasi pemerintah pada sektor pertanian.

2. Tingkat suku bunga riil, dan investasi pemerintah pada tahun sebelumnya, berpengaruh negatif terhadap investasi pemerintah pada sektor pertanian.

\section{Hasil Uji Asumsi Dasar}

\section{HASIL DAN PEMBAHASAN}

Hasil uji One-Sample Kolmogorov-Smirnov Test menunjukkan bahwa data seluruh variabel yang ada dalam persamaan terdistribusi normal. Begitu juga dengan hasil uji multikolinearitas dengan melihat nilai tolerance dan VIF menunjukkan bahwa tidak terdapat korelasi antar variabel independen yang terdapat pada persamaan. Berikut disajikan nilai hasil uji One-Sample Kolmogorov-Smirnov Test dan uji multikolinearitas.

Tabel 1. Uji Asumsi Dasar dan Uji Penyimpangan Asumsi Klasik

\begin{tabular}{lccc}
\hline Variabel & One-sample K-S Test & \multicolumn{2}{c}{ Collinearity Statistics } \\
& & Nilai Tolerance & VIF \\
\hline KPT & 1.191 & \multicolumn{2}{c}{ Dependent Variabel } \\
PAD & 0.952 & 0.292 & 3.426 \\
PEM & 1.038 & 0.549 & 1.822 \\
RIRT & 1.657 & 0.297 & 3.371 \\
ERT & 0.624 & 0.277 & 3.606 \\
KPT & 1.297 & 0.639 & 1.565 \\
PSP & 1.411 & 0.289 & 3.461 \\
\hline
\end{tabular}

Dari hasil analisis diketahui bahwa koefisien determinasi $\left(\mathrm{R}^{2}\right)$ dari persamaan investasi pemerintah adalah bernilai 95,9\%. Angka ini berarti bahwa 95,9\% perubahan (besarnya) tingkat investasi yang dilakukan oleh pemerintah pada sektor pertanian di Provinsi Jambi dapat dijelaskan oleh variabel pendapatan asli daerah, pertumbuhan ekspor impor, riil interest rate, nilai tukar rupiah, besarnya investasi pemerintah yang dilakukan pada tahun sebelumnya, dan tingkat pertumbuhan sektor pertanian di Provinsi Jambi dengan nilai $\mathrm{F}$ hitung signifikan pada level 96,6\% .

$$
\begin{aligned}
\mathrm{KPT}_{g o v}= & 2,830 \mathrm{E} 8+2,077 \mathrm{E}-7 \text { PAD }-0,470 \text { PEM+0,113 RIRT+207662,458 ERT } \\
& +0.966 \mathrm{KPT}_{\text {gov } t-1}-2354,884 \mathrm{PSP}+\mathrm{u}
\end{aligned}
$$

Melalui persamaan juga diketahui bahwa pendapatan asli daerah, tingkat suku bunga riil, nilai tukar rupiah dan investasi pemerintah pada tahun sebelumnya berpengaruh positif terhadap besarnya investasi yang dilakukan oleh pemerintah pada sektor pertanian di Provinsi Jambi. Pendapatan asli daerah signifikan pada level 97,8 \%. 
Jurnal Media Agribisnis Vol. 2 No. 2 Tahun 2017 Hal 85 - 91

Media Komunikasi Hasil Penelitian Bidang Ilmu Agribisnis

ISSN print 2548-7027

ISSN online 2541-6898

Akan tetapi tingkat suku bunga riil dan nilai tukar rupiah tidak berpengaruh signifikan terhadap investasi pemerintah disektor pertanian. Sementara itu, pertumbuhan ekspor impor sektor pertanian dan pertumbuhan sektor pertanian berpengaruh negatif terhadap investasi yang dilakukan oleh pemerintah pada sektor pertanian di Provinsi Jambi dengan nilai t hitung masing-masing signifikan pada level 92,3\% dan 95,3\%. Dengan demikian berarti hipotesis awal untuk $\mathrm{d}_{1}, \mathrm{~d}_{4}>0$ dan $\mathrm{d}_{3}, \mathrm{~d}_{5}<0$ dapat diterima. Sedangkan untuk hipótesis $\mathrm{d}_{2}, \mathrm{~d}_{6}<0$ ditolak, karena tidak sesuai dengan hipótesis awal yang menduga bahwa $\mathrm{d}_{2}, \mathrm{~d}_{6}>0$.

Tabel 2. Hasil Uji t

\begin{tabular}{cccc}
\hline Model & Nilai Koefisien & t & Sig \\
\hline (Constant) & $2,83 \mathrm{E}+08$ & 0,079 & 0,942 \\
PAD & $2,08 \mathrm{E}-07$ & 4,354 & 0,022 \\
PEM & $-0,47$ & $-2,654$ & 0,077 \\
RIRT & 0,113 & 0,38 & 0,729 \\
ERT & 207662,458 & 0,508 & 0,647 \\
KPTgovlag & 0,966 & 5,642 & 0,011 \\
PSP & $-2354,884$ & $-3,255$ & 0,047 \\
\hline
\end{tabular}

Dari persamaan diatas terlihat bahwa pendapatan asli daerah akan berkorelasi positif terhadap investasi pemerintah. Dengan kata lain, semakin tinggi pendapatan asli daerah maka pemerintah akan berinvestasi lebih pada sektor pertanian. Ini dikarenakan semakin tinggi pendapatan asli daerah yang dimiliki oleh pemerintah, berarti persediaan dana yang dimiliki oleh pemerintah semakin besar. Sehingga mendorong pemerintah untuk berinvestasi.

Selain pendapatan asli daerah, perilaku investasi pemerintah juga dipengaruhi oleh laju ekspor-impor sektor pertanian. Dimana, semakin tinggi net export sektor pertanian, investasi yang dilakukan oleh pemerintah akan semakin berkurang. Dengan adanya kegiatan ekspor - impor maka secara tidak langsung akan menambah arus dana yang masuk melalui perluasan pasar domestik ke pasar internasional. Hal ini menunjukkan ketika terjadi pertumbuhan net ekspor yang semakin tinggi pemerintah mulai mengurangi investasinya dan membuka kesempatan yang lebih luas pada pihak swasta untuk berinvestasi pada sektor pertanian.

Kegiatan investasi tidak terlepas dari pengaruh rill interest rate dan exchange rate. Pada persamaan investasi pemerintah diatas terlihat adanya korelasi positif dari real interest rate. Padahal dalam aktivitas atau kegiatan investasi, tingkat suku bunga akan berpengaruh negatif terhadap kagiatan investasi. Pengaruh negatif ini adalah karena dengan tingginya tingkat suku bunga akan mengakibatkan return on investment dari kegiatan investasi menjadi semakin kecil. Dengan kata lain, tingginya tingkat suku bunga dapat mengakibatkan kegiatan investasi menjadi tidak menguntungkan.

Akan tetapi persamaan perilaku investasi pemerintah pada sektor pertanian di Provinsi Jambi yang telah dibuat dalam penelitian ini menunjukkan bahwa tingkat suku bunga berkorelasi positif terhadap investasi pemerintah. Jika ditinjau lebih rinci, maka salah satu alasan yang dapat menjelaskan hal ini adalah bahwa kegiatan investasi pemerintah disektor pertanian adalah lebih dikarnakan kebijakan pemerintah untuk menstimulasi perkembangan perekonomian suatu sektor dalam perekonomian wilayahnya. Sehingga pemerintah lebih fokus kepada multiplier effect dari faktor lain, 
Jurnal Media Agribisnis Vol. 2 No. 2 Tahun 2017 Hal 85 - 91

Media Komunikasi Hasil Penelitian Bidang Ilmu Agribisnis

ISSN print 2548-7027

ISSN online 2541-6898

misalnya faktor pendapatan asli daerah. Jadi, selama dengan melakukan investasi pemerintah dapat meningkatkan output dari sektor pertanian yang nantinya akan menambah pendapatan daerah, pemerintah akan tetap melakukan investasi meskipun tingkat suku bunga terus meningkat. Hal ini juga menjelaskan mengapa tingkat pertumbuhan output sektor pertanian berkorelasi positif terhadap kegiatan investasi pemerintah pada sektor ini.

Sementara itu, nilai tukar rupiah mempengaruhi investasi pemerintah lebih kepada jika terjadi kegiatan ekspor dan impor yang terjadi di sektor pertanian. Dimana jika nilai mata uang rupiah melemah akan mempengaruhi nilai net export yang didapat. Apalagi jika adanya input-input sektor pertanian yang harus di impor dari luar. Akan tetapi hasil penelitian ini menunjukkan bahwa nilai tukar rupiah tidak berpengaruh signifikan.

\section{KESIMPULAN}

Berdasarkan hasil penelitian yang telah dikemukakan di atas, maka dapat ditarik kesimpulan bahwa 95,9\% penyerapan investasi pemerintah pada sektor pertanian di provinsi Jambi dapat dijelaskan oleh variabel pendapatan asli daerah,pertumbuhan ekspor-impor sektor pertanian, tingkat suku bunga riil, nilai tukar rupiah, investasi pemerintah pada tahun sebelumnya, dan pertumbuhan sektor pertanian. Dari faktorfaktor tersebut yang berpengaruh signifikan adalah Pendapatan asli daerah, pertumbuhan ekspor impor sektor pertanian, investasi pemrintah pada tahun sebelumnya dan pertumbuhan sektor pertanian.

\section{DAFTAR PUSTAKA}

Arief S. 1993. Metodologi Penelitian Ekonomi. UI- Press. Jakarta.

BPS .2010. Jambi Dalam Angka Tahun 2010. Badan Pusat Statistik. Jambi.

BPS .2015. Jambi Dalam Angka Tahun 2016. Badan Pusat Statistik. Jambi.

Gaspersz, V. 1991. Ekonometrika Terapan 2. Transito. Bandung.

Hadi H. 2004. Ekonomi Internasional: Teori dan Kebijakan Perdagangan Internasional Edisi Revisi. Ghalia Indonesia. Jakarta.

Hutabarat B. 2001. Investasi Publik Pada Sektor Pertanian di Era Otonomi. Pusat Penelitian dan Pengembangan Sosial Ekonomi Pertanian Badan Penelitian dan Pengembangan Pertanian Departemen Pertanian. Jawa Barat.

Irawan A. 2007. Target Ekspor Komoditas Pertanian dan Kendala Pencapaiannya. Artikel Online.

Koutsoyianis, A. 1977. Theory Of Econometrics An Introduction Exposition Of Econometrics Methods. Barners and Noble Books. New York, USA.

Nanga M. 2005. Makro Ekonomi Teori, Masalah, dan Kebijakan Edisi Kedua. PT Raja Wali Grafindo Persada. Jakarta.

Rusastra I W et al. 2005. Laporan Akhir Analisis Ekonomi Ketenaga Kerjaan Sektor Pertanian dan Pedesaan Indonesia. Pusat Penelitian dan Pengembangan Sosial Ekonomi Pertanian Badan Penelitian dan Pengembangan Pertanian Departemen Pertanian. Jawa Barat.

Tarigan R. 2005. Ekonomi Regional: Teori dan Aplikasi Edisi Revisi. Bumi Aksara, Jakarta. Hal 49-51, 52-53. 